DOI 10.4467/2543733XSSB.17.034.8332

IRENA STAWOWY-KAWKA

Uniwersytet Jagielloński

\title{
MAŁE GRUPY MNIEJSZOŚCIOWE NA BAŁKANACH I PROBLEM ICH SAMOIDENTYFIKACJI: PROCESY TRANSGRESJI NA PRZYKŁADZIE GORANÓW
}

\author{
Słowa kluczowe: transgresja, Gora, Goranie, Kosowo, tożsamość etniczna
}

Charakterystyczną cechą wielokulturowego, wieloetnicznego społeczeństwa, w którym istnieją różnorodne wzorce zachowania i systemy wartości, są procesy transgresyjne, przejawiające się w przekraczaniu konwencji społecznych, dekonstruowaniu założeń z góry przyjętych dotychczas w danej grupie, odejściu od istniejącego modelu adaptacyjnego w kierunku nowego, uczeniu się innej kultury, dostosowaniu się do niej, często w celu unikania konfliktów czy polepszenia swych dotychczasowych warunków życia. W konsekwencji następuje budowanie nowych wspólnot i zmiana deklarowanej tożsamości w zależności od czynników historycznych, sytuacji ekonomicznej, procesów dziedziczenia lub ich nabywania, a przede wszystkim samookreślenia - Ja wobec Ty jako kogoś obcego. W artykule wykorzystano teorię Józefa Kozieleckiego, która stanowi oś merytoryczną rozważań w jego pracy Transgresja i kultura ${ }^{1}$. Działania transgresyjne są działaniami typu „poza”wychodzeniem poza aktualne potrzeby, zmianą w istniejącym status quo ${ }^{2}$. Jednocześnie w tym przypadku transgresja kierowana jest „,ku ludziom” - albo po to, by jednoczyć się (tzw. transgresje wspólnotowe), albo by kierować innymi (transgresje władcze) ${ }^{3}$. Zjawiska te można obserwować szczególnie wyraźnie wśród małych grup etnicznych, żyjących na pograniczach państw narodowych lub wokół innych społeczności narodowych, etnicznych i religijnych. Przechodzenie z jednej grupy do drugiej i przyjmowanie odmiennego modelu kompetencji, wzorców zachowań kulturowych, charakterystyczne jest wśród małych grup mniejszościowych żyjących na Bałkanach. Przedmiotem artykułu jest pokazanie przypadków transgresji i procesów im towarzyszących, które na Bałkanach mają nieba-

1 J. Kozi elecki, Transgresja i kultura, Warszawa 2002; zob. także: i de m, Koncepcja transgresyjna człowieka, Warszawa 1987; idem, Człowiek wielowymiarowy, Warszawa 1996.

2 J. Kozielecki, Koncepcja..., s. 44.

${ }^{3}$ Ibidem; zob. także: W. S zew c zy k, Zachowania transgresyjne - próba psychologicznego pomiaru, „Przegląd Psychologiczny”, 2010, t. 53, nr 4, s. 160. 
gatelne znaczenie. Dla ich zilustrowania posłużę się przykładami żyjących na pograniczu Albanii, Kosowa i Macedonii mieszkańców regionu Gora, nazywanych Goranami, którzy są obiektem zainteresowania zarówno socjologów, jak i kulturoznawców, historyków czy językoznawców, a literatura naukowa na temat ich życia, kultury i języka stale wzrasta. Najnowsza monografia o Goranach, napisana przez Thomasa Schmidingera uwzględnia większość tych aspektów ${ }^{4}$. Bogata jest literatura serbska, macedońska ${ }^{5}$ oraz albańska ${ }^{6}$. Artykuły pisane przez polskich badaczy: Adama Balcera i Jolantę Mindak-Zawadzką nie wyczerpują tematyki. O samoidentyfikacji etnicznej na zamieszkałym przez Goranów obszarze, przesądza w głównej mierze jednoreligijność (islam), w mniejszym stopniu język, którym mówią w domach, gdyż w pracy, szkołach, urzędach, w zależności od miejsca zamieszkania - posługują się albańskim, serbskim, macedońskim. Niemniej jednorodność w wymiarze religijnym i językowym (tym mówionym w domu) nie wystarcza do wspólnego określenia swojej etniczności w okresie transformacji polityczno-ustrojowej, niepozbawionej rozmaitych konfliktów, zagrożeń i napięć. Tożsamość, która powstaje w interakcji z innymi ludźmi i grupami, została zakłócona, nastąpił jej kryzys, który widoczny jest wśród Goranów, na nowo poszukujących swojego ja. Aby stworzyć możliwości samorealizacji, zdolni są oni do przekraczania granicy własnej kultury, norm społecznych, szukania warunków do funkcjonowania w nowej rzeczywistości. Dochodzenie do własnej tożsamości utrudnia Goranom nie tylko fakt, że żyją w różnych państwach, oddzieleni granicami, ale i że mieszkają w otoczeniu rozmaitych grup narodowych, etnicznych i religijnych. Ważny jest także fakt, że swą gorańską tożsamość mogą określać w Kosowie, natomiast w Macedonii i Albanii nie są oficjalnie uznawani za oddzielną mniejszość etniczną.

Jak twierdzi M. W. Poznańska:

Dochodzenie do własnej tożsamości jest długą, mozolną pracą nad sobą, a trudności w kreowaniu swojego $<j a>$ są konsekwencją istniejących warunków społecznych, które nie zawsze stwarzają możliwości do samorealizacji, bo nie są wolne od konfliktów i zagrożeń, napięć i sprzeczności. Uczymy się zaspokajać potrzeby poprzez wrastanie w świat norm społecznych i wartości kulturowych ${ }^{8}$.

${ }^{4}$ T. Schmidinger, Gora: slawischsprachige Muslime zwischen Kosovo, Albanien, Mazedonien und Diaspora, Wien 2013. Ukazała się też praca dotycząca sztuki ludowej Goran: T. Çoruhlu, „Kayıp mirasın ízinde”. Gora. Halk Sanatlari, İstanbul 2007.

${ }^{5}$ W roku 2017, już po napisaniu tego tekstu, ukazała się publikacja pochodzącego z Macedonii Goranina D. A dži j a, Oblasta Gora. Kratok istoriski i etnogeografski pregled, Skopje 2017.

${ }^{6}$ Горанци, муслимани и Турии у Шарпланинским жупама Србије: Проблеми садашьих услова живота и опстанка, red. М. Бурсаћ, Београд, 2000, http:/www.rastko.rs/rastko-gora/zbornici/gora2000/mradovanovic.pdf; Ј. Ц в и ј и ћ, Антропогеографски и етнографски списи, књига 4, 1987, Београд 1987; Б. В ид о е с к и, Горанскиот говор, „Прилози”, Скопје 1986, t. XI, z. 2, s. 3-16; S. G a s h i, Goranët dhe 'Boshnjakët'Nërskamëz tjetër për Kosovën!?, ,Revista Sharri”, 2012, http://pashtriku.beepworld.de/files/Histori/sharri/sharri_11_12_11.pdf, s. 24-29 (dostęp 1.09.2016). Zob. artykuł polemiczny: Q. M a t e j, Polemikë me shkas. Njohja e historisë apo kërkesa politike për. Gorën dhe goranë, Përgjigje artikullit të NazifDoklit “Gora dhe goranët” Kukës 1991, http://pashtriku.beepworld.de/files/Histori/shpalime/qemal_mataj_goranet.27.06.08.htm (dostęp: 1.09.2016).

${ }^{7}$ A. B a l c e r, Goranci - społeczność stowiańskich muzulmanów na pograniczu albańsko-macedońskim w poszukiwaniu tożsamości, [w:] Tożsamość narodowa w społeczeństwie multietnicznym Macedonii, red. M. Kawka, I. Stawowy-Kawka, Kraków 2008, s. 192-209; J. M in d a k-Z a w a d z k a, Gorani- , lokal” People?, Sprawy Narodowościowe, 2007, z. 31, s. 213-225.

${ }^{8}$ M. W. Poznańska, Tożsamość jako element kultury pedagogicznej współczesnego wychowawcy, „Edukacja Dorosłych”, 1995, nr 2, s. 64-65. 
Goranie lub Gorańcy (mac. Горани, alb. Goranë) osiedlili terytorium na granicy Kosowa, Albanii i Macedonii. Nazwa Goranie pochodzi od regionu Gory - Góry, są to górale, zamieszkujący górzyste pasmo Šar Planiny. Ich populacja szacowana jest przez badaczy na 50 do 60 tys. ${ }^{9}$ Ze względu na dużą migrację ich liczba w Gorze kurczy się, a sami Albańczycy podają (według spisu ludności w Kosowie z 2011 r.), że jest ich w gminie Dragaš (serb. - cyrylica Драгаш, alb. Dragash lub Sharri), leżącej na południowym zachodzie Kosowa, ok. 13 tys. ${ }^{10}$, w Albanii -9 tys. ${ }^{11}$, a w Macedonii $-1355^{12}$. Według oficjalnego spisu ludności przeprowadzonego w Kosowie w 2011 r. na 33997 mieszkańców gminy Dragaš - 20287 było Albańczykami (59, 67\%), z kolei Goranów było 8957 (26,35\%) i 4100 Boszniaków (12,06\%). Reszta, tj. 1,92\% deklarowała się jako Turcy, Serbowie, Romowie, Egipcjanie i inni ${ }^{13}$.

Największym centrum administracyjnym Gory jest wieloetniczne dzisiaj miasteczko Dragaš, liczące około 1 tys. mieszkańców, do niedawna zamieszkałe niemal wyłącznie przez Goranów. W 2011 r. na 1098 mieszkańców - Goranów było 567, a Albańczyków 498, reszta to Boszniacy - 18, Turków - 7 i 8 osób innych narodowości. Największa gorańska wieś - Restalica liczy niecałe 4,7 tys. Goranów, którzy żyją w ponad 1,5 tys. domostw, gdyż duża ich część wyjechała w poszukiwaniu pracy do byłych republik Jugosławii oraz na Zachód. Obecnie w Kosowie Goranie zamieszkują 18 wiosek. W Albanii jest 9 wsi gorańskich, a w Macedonii - 2. Liczba Goranów ulega zmniejszeniu, nie tylko ze względu na liczne migracje zarobkowe i polityczne, ale także na skutek zmiany samoidentyfikacji.

\section{II}

Nasuwa się pytanie, co jednoczy (scala) tę małą społeczność, dlaczego mimo rozmaitych trudności - samoidentyfikują się jako Goranie?

Po pierwsze czynnikiem scalającym jest religia. Goranie to słowiańska ludność muzułmańska (sunnici), która przyjęła islam w okresie panowania Osmanów. Naukowcy podkreślają, że odrzucając bogomilstwo, przeszli na islam ${ }^{14}$. Inne nurty religii islamskiej

${ }^{9}$ Dane te dotyczą również diaspory. S. G a s hi, Goranët dhe 'Boshnjakët'..., http://pashtriku.beepworld. de/files/Histori/histori_2011/skender_gashi_goranet_boshnjaket_11.10.11.htm, ocenia, że w sumie żyje dzisiaj około 30 do 40 tys. Goranów (dostęp: 10.11.2016).

${ }^{10}$ Spis ludności w Kosowie z 2011 r., http://pop-stat.mashke.org/kosovo-census-rs.htmw, (dostęp: 10.11.2016).

${ }^{11}$ Ibidem.

${ }^{12}$ Dane te sporządzono, sumując liczbę ludności zamieszkującej 2 gorańskie wsie w Macedonii, wg spisu ludności w 2002 r.

${ }^{13}$ Spis ludności w Kosowie z 2011 r., http://pop-stat.mashke.org/kosovo-ethnic-loc2011.htm, (dostęp: 10.11.2011).

${ }^{14}$ S. Gashi w pracy: Goranët dhe 'Boshnjakët'... dowodzi, że Goranie - podobnie jak Pomacy żyjący obecnie w Grecji (Tracja Zachodnia), Torbeše w Macedonii mają to samo pochodzenie. Natomiast Fred Cocozzelli w artykule Ethnic Boundaries and Politics in Kocovo, [w:] Ethnic Minorities and Politics in Post-Socialist Southeastern Europe, red. S. P. Ramet, M. Valenta, Cambridge 2016, s. 272, 273, mylnie podaje, iż Torbeše zamieszkują Kosowo (a nie Macedonię), a brak mobilizacji politycznej wśród nich doprowadził do samoidentyfikacji jako „Macedończycy - Muzułmanie” lub „Torbeše”. W okresie gdy Macedonia wchodziła 
Mapa nr 1. Rozmieszczenie ludności Gory

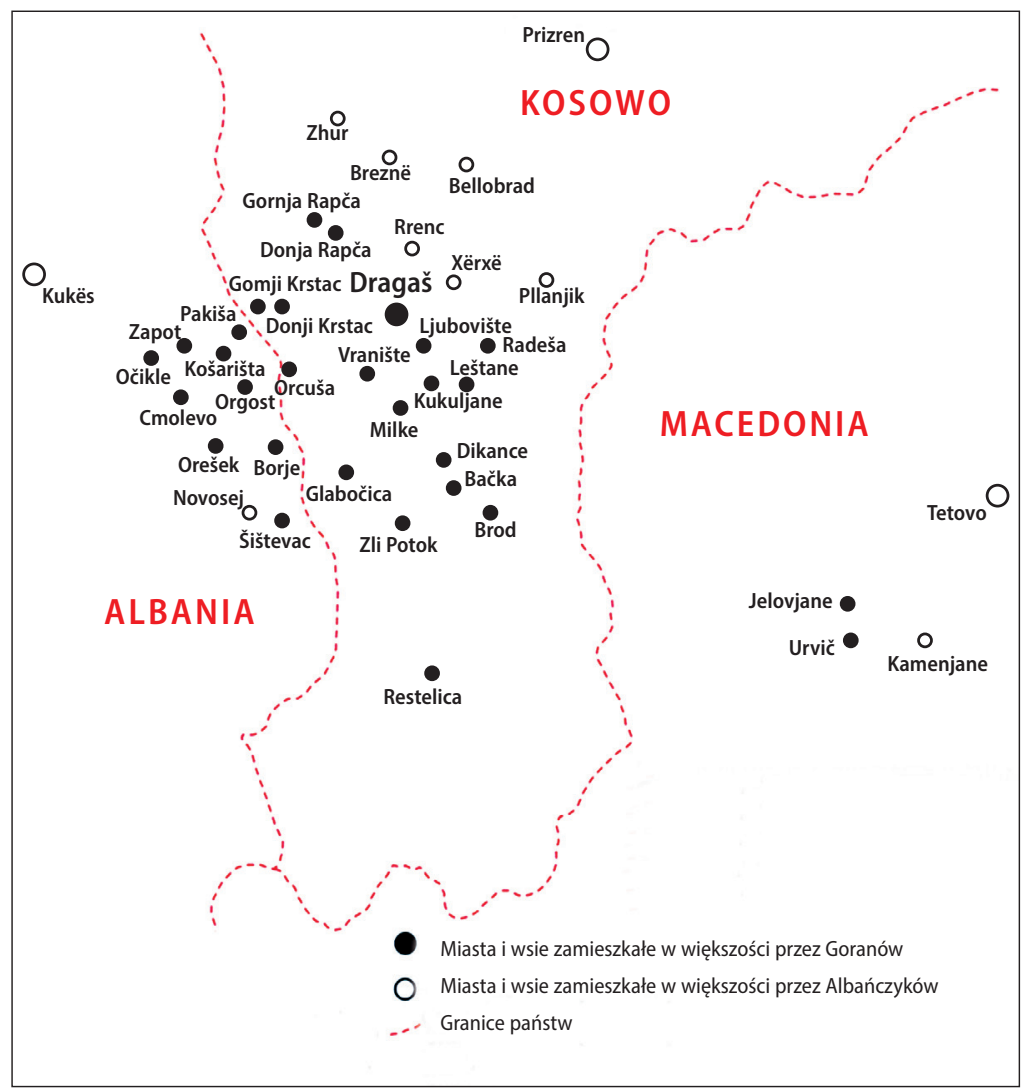

Mapa opracowana na podstawie monografii: T. Schmidinger, Gora: slawischsprachige Muslime..., s. 12.

w skład Jugosławii, władze starały się utrzymać jedność etniczną Macedończyków, sprowadzając różnice religijne do dziedziny prywatnych wyborów, co z polityką sekularyzacji, zmierzającą do marginalizacji religii instytucjonalnych w samej Macedonii, nie odnosiło spodziewanych efektów. Władze w Skopiu popierały działalność w ramach utworzonej przez Nijaziego Limanovskiego Republikańskiej Wspólnoty Kulturalno-Naukowych Manifestacji Macedończyków - Muzułmanów. Organizacja ta, urządzając wiece i konferencje oraz wskazując, że islam obok prawosławia jest religią typowo macedońską, starła się o podtrzymanie macedońskiej świadomości narodowej. W 2006 r. przedstawiciele Torbešów, na czele z Fijatem Canovskim, utworzyli Partię na rzecz Przyszłości Europejskiej (Partija za evropska idnina PEI). W jej skład weszli przedstawiciele różnych wspólnot etnicznych z zachodniej Macedonii, a w parlamencie zyskali 1 deputowanego. Na forum parlamentu Canovski wziął w obronę Torbešów, którzy nie byli uznawani za osobną wspólnotę etniczną, co powodowało, że nie mieli swej oddzielnej reprezentacji w urzędach państwowych, administracji i instytucjach publicznych (policji i wojsku) proporcjonalnie do swojej liczebności. Wydzielenie osobnej wspólnoty etnicznej miało pokazać różnice kulturowe, religijne, obyczajowe (etnicznej endogamii) między Macedończykami - prawosławnymi i Macedończykami - muzułmanami, tak duże, że ci ostatni zasługiwali, aby stworzyć osobną wspólnotę etniczną, a tym samym zyskać w Macedonii „należne im prawa”. Był to proces odwrotny do proponowanego wcześniej, gdy starano się minimalizować różnice religijne i kulturowe między Macedończykami różnego wyznania. W czasie wyborów parlamentarnych w 2011 r. partia ta straciła swe przedstawicielstwo parlamentarne. 
nie znalazły wyznawców wśród tej ludności. Wpływy salafickie i wahabickie widoczne są głównie w Rapčy, Kruševie, Restalicy za sprawą pochodzących z tych miejscowości emigrantów, którzy znaleźli pracę w Europie Zachodniej. Także bektaszyci nie mają tam wielu zwolenników, chociaż w Restelicy znajduje się tekke. Natomiast ciekawym zjawiskiem jest np. obchodzenie przez Goranów jednego z największych świąt należących do tradycji chrześcijańskiej - święta św. Jerzego (buł. Гергьовден, тас. Ѓурѓовден, serb. Djurdjevdan), nie jako uroczystości kościelnej, ale jako początku wiosny, co roku dnia 6 maja. Wówczas Goranki wkładają swe tradycyjne stroje, tj. czarne płaszcze obszywane złotą, srebrną lub inną lamówką, natomiast młode niewiasty białe stroje. Jest to jedno z największych świąt Goranów.

Po drugie, ogniwem scalającym Goranów jest ich język, używany w życiu codziennym. Goranie mówią dialektem południowo-słowiańskim, zwanym „našinskim”, czyli „naszym”15. Najbardziej zbliżony jest do języka macedońskiego lub serbskiego. Macedończycy wręcz określają go jako macedoński. Języka tego używa się przede wszystkim ustnie, chociaż pojawiają się także utwory pisane. Są to głównie wiersze, wiele tekstów piosenek, również proza. Język ten nie posiada w żadnym z krajów zamieszkałych przez Goranów statusu oficjalnego. Do największych współczesnych pisarzy należą: Nazaif Dokle z Borje w Albanii, Mustafa Balje z Restelicy w Kosowie, z kolei z Kruševa w Kosowie - Sadik Idrizi Aljabak oraz Ramadan Redžepi ze Zlipotok w Kosowie i inni. W Kosowie i Macedonii wśród Goranów obowiązuje alfabet cyryliczny, a w Albanii łacinka. Ponieważ brakuje szkolnictwa w języku „našinskim”, nie istnieją też media, ani literatura dla dzieci, a inteligencja jest nieliczna, zmniejsza się znaczenie języka jako czynnika scalającego.

Po trzecie, Goranów jednoczy tradycja, wynikająca z życia w enklawie, w której kultywuje się określone - znamienne tylko dla tej grupy - wierzenia i zwyczaje. Pociąga to za sobą wyróżniający styl życia, którego przejawem jest choćby specyficzne organizowanie wesel, odbywających się głównie w nocy, używanie jedynych w swoim rodzaju instrumentów muzycznych (z grupy drewnianych dętych surma, mac. зурла, tur. zurna), urządzanie obrzędów obrzezania 10-letnich chłopców, czy popularność wieczornych spotkań młodych ludzi na głównej ulicy lub rynku miejscowości (korzo). Należy podkreślić, że wśród Goranów obowiązuje tradycyjny podział ról męskich i żeńskich, a małżeństwo pojmowane jest jako związek monogamiczny ${ }^{16}$.

\section{III}

Oprócz czynników, które jednoczą: religii, języka i tradycji, istnieją przesłanki powodujące brak jedności wśród Goranów, które w okresie transformacji polityczno-ustrojowej i rozmaitych konfliktów są na tyle poważne, że wspólne określenie swej tożsamości etnicznej nie jest możliwe.

${ }^{15} \mathrm{~W}$ dialekcie torlačkim ludzie mówią w południowej i wschodniej Serbii, północno-zachodniej Macedonii (Kratovo-Kumanovo) oraz zachodniej Bułgarii (Belogradčik-Trn-Breznik).

${ }_{16}$ Д. Антонјевиђ nazywa to ,życiowym cyklem rytualnym”, zob. i d e m, Етнички идентитет Горанцุа, s. 25, https://www.rastko.rs/rastko-gora/zbornici/gora2000/dantonijevic.pdf, (dostęp: 10.11.2016). 
Po pierwsze są to granice państwowe. Goranie żyją w trzech dzisiaj niezależnych państwach: Albanii, Kosowie i Macedonii. Granice, które wytyczono po wojnach bałkańskich 1912/1913 i które w latach 1925 i 1926 uległy niewielkiej regulacji ${ }^{17}$, podzieliły górali żyjących w Gorze na tych mieszkających w Albanii oraz tych w Serbii, a potem w Królestwie SHS (Jugosławii). Po II wojnie światowej doszło do korekty granicy między republikami związkowymi Jugosławii - Serbią i Macedonią ${ }^{18}$. Podczas gdy Kosowo-Metochia była autonomicznym obwodem w ramach Serbii, dwie wsie: Urvič i Jelovjane znalazły się w granicach Macedonii. Proklamowanie niezależnej Republiki Macedonii w 1991 r. spowodowało powstanie granicy państwowej między Jugosławią i Macedonią, a w 2008 r., po ogłoszeniu deklaracji niepodległości przez Kosowo, granicy kosowsko-macedońskiej. Istnienie tych granic miało dla jedności Goranów niebagatelne negatywne znaczenie.

Po drugie - różnice w uregulowaniach prawnych dotyczących mniejszości narodowych, etnicznych i religijnych w poszczególnych krajach, w których żyją Goranie, są kolejnym czynnikiem niesprzyjającym jedności. W Albanii uznawane są tylko te mniejszości narodowe, etniczne i religijne, które zamieszkują tzw. strefy mniejszościowe ${ }^{19}$. Obszar, gdzie żyją Goranie, nie podlega takim regulacjom, gdyż na terytorium tym nie stworzono strefy mniejszościowej. Oni sami natomiast - w zależności od swoich interesów i wpływów, którym ulegają - określają się jako Macedończycy lub Bułgarzy. W Albanii, gdzie oficjalnie nie przyjmuje się istnienia mniejszości gorańskiej, są oni uznawani za Albańczyków. Natomiast w Kosowie wyróżnia się (oficjalnie) Goranów jako mniejszość etniczną, ale nie wszyscy z nich z taką mniejszością się identyfikują. Przyjmują oni tożsamość boszniacką, gorańską lub rzadziej albańską lub turecką. Rośnie jednak wśród nich przekonanie o potrzebie samoidentyfikacji gorańskiej. W Macedonii Goranie uznawani są za Macedończyków.

\section{IV}

Przyczyną różnorodnej samoidentyfikacji i procesów transgresyjnych była polityka państw, w których żyją Goranie, lub sąsiednich państw bałkańskich, a także trudne warunki ekonomiczne tej ludności. Jak podaje Sadik Idrizi, po drugiej wojnie światowej wielu Goranów, żyjących wówczas w Jugosławii, bo aż 36,6\%, podawało się, podobnie jak Albańczycy, za Turków, by w obawie przed prześladowaniami komunistycznymi móc

${ }_{17}$ Dokładniej zob. I. S taw ow y-Kaw ka, Albańczycy $w$ Macedonii 1944-2001, Kraków, 2014, s. 32; e a d e m, Granice Albanii - najważniejsze daty, [w:] Tantum Historiae. Ksiegga ofiarowana profesorowi Mieczysławowi Tantemu w osiemdziesiąta rocznicę urodzin, red. P. Żurek, Bielsko-Biała 2008, s. 138-151.

18 J. D. Talev s ki, The Borders of the Republic of Macedonia, Bitola 1998, s. 34 i 35 . Decyzję o zmianach terytorialnych podjęto na posiedzeniu Prezydium ASNOM 30 września 1945 r. (Службен весник на ДФМ, бр. 17/45). Zmiany granic dokonano 21 listopada 1945 r. (Службен весник на ДФМ, бр. 24/45).

19 Po reformie administracyjnej w Albanii w 2015 r. rolę „stref mniejszościowych” przejęły powiaty (alb. bashki), których jest 61. W dwóch z nich uznaje się mniejszość grecką, a w jednym macedońską. LIGJ, Nr 139/2015, PËR VETËQEVERISJEN VENDORE Art. 93, Aktualizowanie granic administracyjno terytorialnych, (alb. Përditësimi i kufijve administrativo-territorialë), https://www.parlament.al/wp-content/uploads/2016/01/ligj_ nr_139_dt_17_12_2015_25082_1.pdf, (dostęp: 10.11.2016). 
wyjechać do Turcji. Surowe represje wprowadzane przez Aleksandara Rankovicia, ówczesnego ministra spraw wewnętrznych Jugosławii i szefa tajnej policji po drugiej wojnie światowej, powodowały zmianę nazwisk przez Goranów na tureckie przez dodanie cząstki: -lar, -ler, -oglu. Tym, którym nie udało się wówczas migrować do Turcji, do dzisiaj pozostały obco brzmiące nazwiska ${ }^{20}$. Zmiana identyfikacji przez Goranów na turecką była zatem rezultatem sytuacji politycznej w Kosowie, dla której znamienne było zastraszanie przeciwników komunistycznego państwa, stosowanie wobec nich terroru i kary więzienia oraz brak wiary, że komunistyczne państwo pozwoli na praktyki religijne w przyszłości. Wprawdzie Tito i jego współpracownicy bezpośrednio po wojnie starali się zaszczepić politykę „,braterstwa i jedności”, tj. wspólnego jugosłowiańskiego bytu, jednocześnie nadając narodom i mniejszościom narodowym szereg praw kulturalnych, jednak należy pamiętać, że monopolizacja władzy przez komunistów przebiegała w Jugosławii w sposób skuteczny, szybki i krwawy, czego bali się Goranie - wyznawcy islamu.

Liberalizacja życia w Jugosławii w latach 60. spowodowała poprawę sytuacji Goranów. Już w czasie spisu powszechnego z 1961 r. w Bośni i Hercegowinie używano terminu - Muzułmanin w sensie etnicznym. W 1968 r. Związek Komunistów Bośni i Hercegowiny proklamował ${ }^{21}$ istnienie narodu zwanego - Muzułmanie, rezerwując ten termin dla Słowian wyznania muzułmańskiego. Ustawa zasadnicza Bośni i Hercegowiny z 1974 r. wprowadzała prawną możliwość określania swej tożsamości jako Muzułmanin ${ }^{22}$, co stało się powszechnie stosowaną normą nie tylko w Bośni i Hercegowinie, ale w całej Jugosławii. Aż do rozpadu Jugosławii Goranie przyjmowali taką samoidentyfikację dla siebie w Kosowie i Macedonii. Różnica w podejściu do Muzułmanów polegała na tym, że w Bośni i Hercegowinie byli oni traktowani na równi z Serbami i Chorwatami, w Kosowie, podobnie jak Albańczycy, Serbowie czy Turcy, jako oddzielny naród, natomiast w Macedonii jako mniejszość etniczna, która miała te same prawa co naród macedoński i narodowości albańska i turecka. Aż do rozpadu Jugosławii liczba Goranów stale rosła. Według spisów ludności w 1981 r. ponad 17 tys. ludzi w Gorze określiło swą tożsamość jako - Muzułma$n^{23}$. Gdy termin Muzułmanin w sensie narodowym i etnicznym przestał funkcjonować, Goranie ponownie musieli zdefiniować swą tożsamość. Odmienne podejście do tego problemu do dzisiaj różni Goranów, przy czym zauważalne transgresje tożsamościowe miały głównie służyć ich przetrwaniu lub polepszeniu warunków życia. Zwolennikiem przyjmowania przez Goranów tożsamości boszniackiej, która miała ich chronić przed albanizacją, był Sadik Idrizi Aljabak polityk, pisarz i nauczyciel akademicki, cieszący się autorytetem

20 S. I d ri zi, Sto muhadžirskich godina, Pročitajte više na:http://www.info-ks.net/bosnjaci/historija/28438/ sadik-idrizi-sto-muhadzirskih-godina, (dostęp:10.11.2016).

${ }^{21}$ O potrzebie takiej identyfikacji pisał m.in. K. Suljević w pracy: Nacionalnost Muslimana između teorie i politike, Rijeka 1981. W czasie spisu ludności w Jugosławii w 1971 r. dano jej mieszkańcom możliwość określenia swej tożsamości jako - Muzułmanin. Wówczas aż 8,4\% jej mieszkańców przyjęło taką samoidentyfikację.

${ }^{22}$ Konstytucja Bośni i Hercegowiny z 1974 r. w części II Wprowadzenie. Podstawowe zasady (Uvodni dio. Osnovna načela) przewiduje: „Ludzie pracy i obywatele - Chorwaci, Serbowie i Muzułmanie oraz przedstawiciele innych narodów i narodowości realizują w Socjalistycznej Republice Bośni i Hercegowiny jako państwie i samorządowej wspólnocie swe suwerenne prawa i swoje klasowe i narodowe interesy". Zob. Ustav SFRJ. Ustavi Socjalističkih Republika i Pokrajina, Beograd 1974, s. 94.

${ }^{23}$ S. I d ri z i, Sto muhadžirskich..., http://www.info-ks.net/bosnjaci/historija/28438/sadik-idrizi-sto-muhadzirskih-godina, (dostęp:10.11.2016). 
wśród Goranów²4. Po 1990 r. Goranie zgłaszali akces do politycznych partii, które powstały w Bośni i Hercegowinie, a zarejestrowane były na terytorium Serbii, gdy Kosowo jako terytorium serbskie wchodziło w skład Federacji Jugosłowiańskiej złożonej z Serbii i Czarnogóry. W maju 1990 r. jako jedna z pierwszych powstała Partia Akcji Demokratycznej (SDA -Stranka demokratske akcije), jej przewodniczącym został Alija Izetbegović. Jej filia zaczęła też funkcjonować na terenie Kosowa w Dragaš.

Natomiast inni Goranie - choć wyznawali islam, za ważną uznali tradycję chrześcijańską, obchodząc razem z prawosławnymi Boże Narodzenie, którego nie przyjmowali jako święta religijnego; ponadto slawizowali swe nazwiska (nie imiona!). W przeciwieństwie do swych sąsiadów Albańczyków Goranie - tak samo jak Boszniacy - pozostawali wierni Belgradowi, co przejawiało się we wstępowaniu do Partii Socjalistycznej Slobodana Miloševicia lub Serbskiego Ruchu Odnowy Vuka Draškovica, które budowały swe struktury w Dragaš. W latach 90, gdy Serbowie kształtowali na tych terenach zaplecze antyalbańskie, wspierali ich Goranie, z których wielu pracowało wtedy w lokalnej administracji, policji i wojsku. W szkołach nauczanie odbywało się w języku serbskim. Zajęcie takiej postawy przez Goranów powodowało konflikty z albańskimi sąsiadami, z którymi łączyła ich religia - islam, ale nie przekonania polityczne i za te ostatnie Goranie musieli w końcu lat 90. surowo zapłacić. Gdy w 1999 r. rozpoczęła się regularna wojna w Kosowie, wcielani do jugosłowiańskiej armii i policji Goranie stali się, podobnie jak Serbowie, największymi wrogami Albańczyków. Do walki przystąpili nie tylko kosowscy Albańczycy, ale także ci z Albanii i Macedonii, którzy grabili wioski gorańskie, niszcząc ich dobytek, a mieszkańców przepędzali lub mordowali, gdy zachodziło podejrzenie o współpracę z Serbami. Nastąpił masowy exodus ludności, która uciekała przed zagrożeniem. Sytuacja ta trwała do 2001 r., tj. do zakończenia działań zbrojnych w sąsiedniej Macedonii ${ }^{25}$. Obecnie w samej Serbii żyje 7767 Goranów $^{26}$.

Choć obecnie incydenty na tle etnicznym, polegające na ataku fizycznym wobec Goranów, są coraz rzadsze, to nadal do nich dochodzi. Po zaatakowaniu 20 lipca 2009 r. w Dragaš (alb. Dragash) przez grupę Albańczyków Goranina i jego syna największe partie gorańskie: Koalicja Vakat (Koalicija Vakat) ${ }^{27}$, Obywatelska Inicjatywa Goranów (GIG - Građanska Inicijativa Goranaca) oraz Partia Akcji Demokratycznej (SDA) złożyły wspólną deklarację potępiającą zajście, ale nie spotkało się to z żadną reakcją ze strony kosowskich władz lokalnych ${ }^{28}$. Natomiast 19 lipca 2010 r. w Belgradzie w wy-

24 Sadik Idrizi Aljabak, ur. w 1954 r. w Kruševje (alb. Krushevë), poeta, eseista, dr Uniwersytetu w Prizrenie, w latach 2013-2015 prorektor. Wydał prace naukowe z zakresu literaturoznawstwa, folkloru, kultury. W latach 2004-2007 minister zdrowia w Kosowie, 2 kadencje zasiadał w parlamencie Kosowa jako poseł, reprezentujący interesy Goranów z ramienia boszniackiej Demokratycznej Partii Vatan.

${ }_{25}$ Zob. T. S chmidinger, Gora: slawischsprachige Muslime zwischen Kosovo..., s. 72.

${ }_{26}$ Република Србија. Републички завод за статистику, http://webrzs.stat.gov.rs/WebSite/Public/ReportResultView.aspx?rptId=1216, [dostęp: 10.11.2016].

${ }^{27}$ Koalicja Vakat zrzesza Boszniaków w Kosowie, w wyborach parlamentarnych w 2014 r. zdobyła 2 miejsca w parlamencie kosowskim. Obywatelska Inicjatywa Goranów w wyborach parlamentarnych w Kosowie w 2014 r. poparła Serbską Partię Postępową (Srbska Napredna Stranka - lider Aleksandar Vučić). Partia Akcji Demokratycznej, mająca swą siedzibę w Dragaš, w wyborach parlamentarnych uzyskała 1 mandat. W ten sposób Goranie, którzy przyjęli boszniacką tożsamość, zajmują 3 miejsca w 120-osobowym parlamencie Kosowa, natomiast 1 mandat zdobyła partia - Koalicja dla Gory, której członkami są ci o tożsamości gorańskiej.

${ }^{28}$ Kosovo Communities Profiles 2010, 8 February 2011, http://www.osce.org/kosovo/75450, (dostęp: 10.11.2016). 
niku eksplozji ładunku wybuchowego ucierpiał sklep Goranina należącego do GIG. Rannych nie było ${ }^{29}$.

$\mathrm{Na}$ zmianę samoidentyfikacji największy wpływ mają obecnie czynniki językowe i kulturowo-ekonomiczne. Głównym źródłem utrzymania Goranów są drobne firmy prywatne, jak: cukiernie, sklepy spożywcze, część z nich zatrudniona jest w sektorze publicznym lub pracuje na roli. Jednak bezrobocie wśród nich jest wciąż bardzo wysokie. Jak podaje albańska badaczka Blerta Avida, w 2011 r. w sektorze prywatnym pozarolniczym zatrudnionych było $19 \%$ Goranów, $31 \%$ w prywatnym rolniczym, a 38\% w sektorze publicznym. Wychowanie dziewcząt $\mathrm{z}$ uwzględnieniem tradycyjnego podziału ról i wiążący się z tym niski poziom ich wykształcenia sprawiają, że jedynie $15,3 \%$ kobiet ma pracę ${ }^{30}$. Natomiast przy stopie bezrobocia wynoszącej 51, 3\%, sporo osób pracowało „na czarno” jako sprzedawcy uliczni, malarze, mechanicy, budowlani, hydraulicy ${ }^{31}$. Często dążenie do poprawy trudnych warunków życia wymusza na Goranach transgresję tożsamości, dlatego w czasach pokoju za najważniejszy bodziec decydujący o zmianie samoidentyfikacji należy uznać czynnik ekonomiczny. Obecnie część Goranów, aby znaleźć oficjalne zatrudnienie, zadeklarowała swą tożsamość jako albańską. Większość wyjechała za granicę. Ze względu na język, w którym pobierają naukę, docelowym kierunkiem migracji jest Serbia, ale także inne byłe republiki Jugosławii, jak Macedonia, gdzie z kolei podobieństwo do ich języka „našinskiego” jest duże, a warunki życia o wiele lepsze. Dlatego w czasach pokoju czynnik ekonomiczny staje się najważniejszy. Bez względu jednak na sympatie proserbskie, promacedońskie czy probułgarskie obecnie Goranie w Kosowie przyjmują samoidentyfikację gorańską (8 957 osób) oraz boszniacką (4 100 osób) ${ }^{32}$.

Po dramatycznych wydarzeniach z przełomu XX i XXI wieku określenie się na terytorium Gory jako Serb, Macedończyk czy Bułgar jest dzisiaj niepopularne. Coraz częściej jednak, zwłaszcza tam, gdzie Goranie żyją blisko Albańczyków, rodzice posyłają swe dzieci do szkół albańskich. Ismail Bojda ${ }^{33}$, żyjący w górach Šar Planiny, uważa siebie, jak i pozostałych Goranów za Macedończyków. W 2006 r. utworzył towarzystwo gorańsko-macedońskie, a w 2011 r. Macedońską Demokratyczną Partię, która nie została zarejestrowana przez władze kosowskie. Z niewielkim odzewem spotykają się w Kosowie inicjatywy władz bułgarskich skierowane do Goranów. Rządzący w Sofii chętnie dają Goranom paszport bułgarski - co umożliwia im migrację zarobkową do krajów UE lub zapewniają młodzieży bezpłatne studia na uczelniach w Bułgarii. $Z$ tych propozycji chętnie korzystają Goranie z Albanii, natomiast w niewielkiej mierze ci z Kosowa, którzy pamiętają represje Albańczyków z lat 90., gdy opowiedzieli się po stronie serbskiej.

${ }^{29}$ Napad na radnju Goranca u Beogradu,http://www.naslovi.net/tema/193621, (dostęp: 10.11. 2016).

${ }^{30}$ B. Avi d a, Vlerësimi dhe menaxhimi i resurseve natyrore dhe njerëzore të krahinave lumë-Gorë (Kosovë) për zhvillimin e qëndrueshëm tëtyre, Tiranë 2015, s. 101, http://www.doktoratura.unitir.edu.al/wp-content/ uploads/2016/10/FNAL-DOKTORATURA-BLERTA-AVDIA.pdf, (dostęp: 10. 11. 2016).

${ }^{31}$ Ibidem, s. 100, 101.

32 Spis ludności w Kosowie z 2011, http://pop-stat.mashke.org/kosovo-census-rs.htmw, (dostęp: 10.11.2016).

${ }^{33}$ W 2012 r. w Skopiu wyszła praca o poglądach Ismaila B ojdy pt. Во потрага на националниот идентитет. Wyboru tekstów i redakcji dokonała Ž. Trpevska. Ismail Bojda jest przewodniczącym Związku Macedończyków Religii Islamskiej - Goraninem z Kosowa. 


\section{Podsumowanie}

Uwarunkowany historycznie i politycznie kryzys tożsamościowy Goranów trwa, chociaż trzeba zauważyć, że obecnie górale z Šar Planiny coraz częściej przyjmują tożsamość gorańską - neutralną, daleką od bieżącej polityki. Wydanie książki w języku „našinskim", najmniejszego tomiku poezji jest wydarzeniem, które świętuje cała społeczność bez względu na granice państwowe. Napięcia i konflikty w regionie sprawiają, że budowanie tożsamości przez Goranów jest żmudne. Jednak w świecie zmieniających się norm i wartości - zważywszy na albańskie sąsiedztwo i brak perspektyw na poprawę warunków ekonomicznych - trudno będzie małej gorańskiej społeczności swoją z trudem kształtowaną odrębność utrzymać. Dalsze procesy transgresji, przechodzenia Goranów z jednej grupy do drugiej, w tym wypadku do grupy Albańczyków, i przyjmowanie odmiennego modelu kompetencji, wzorców zachowań kulturowych jest w niedalekiej przyszłości nieuniknione. Warunkują to głównie trudne warunki ekonomiczne Goranów, jak i życie w enklawie wśród Albańczyków.

\section{Bibliografia}

Dokumenty, raporty, statystyki:

Cvilijić J., Antropogeografski i etnografski spisi, z. 4, Beograd 1987. (Ј. Цвијић, Антропогеографски и етнографски списи, књига 4, Београд 1987).

Kosovo Communities Profiles, 2010, 8 February 2011, http://www.osce.org/kosovo/75450

Služben vesnik na DFM, br. 17/45 (Службен весник на ДФМ, бр. 17/45).

Služben vesnik na DFM, br. 24/45 (Службен весник на ДФМ, бр. 24/45).

Spis ludności w Kosowie z 2011 r., http://pop-stat.mashke.org/kosovo-census-rs.htmw.

Ustav SFRJ. Ustavi Socjalističkih Republika i Pokrajina, Beograd 1974.

Monografie:

Adžija D., Oblasta Gora. Kratok istoriski i etnogeografski pregled, Skopje 2017.

Avida B., Vlerësimi dhe menaxhimi i resurseve natyrore dhe njerëzore të krahinave lumë-Gorë (Kosovë) për zhvillimin e qëndrueshëm tëtyre, Tiranë 2015, s. 101, http://www.doktoratura.unitir. edu.al/wp-content/uploads/2016/10/FNAL-DOKTORATURA-BLERTA-AVDIA.pdf (doktorat).

Çoruhlu T., „Kayıp mirasın izinde”. Gora. Halk Sanatlari, İstanbul 2007.

Kozielecki J., Transgresja i kultura, Warszawa 2002.

Kozielecki J., Koncepcja transgresyjna człowieka, Warszawa 1987.

Kozielecki J., Człowiek wielowymiarowy, Warszawa 1996.

Schmidinger T., Gora: slawischsprachige Muslime zwischen Kosovo, Albanien, Mazedonien und Diaspora, Wien 2013.

Stawowy-Kawka I., Albańczycy w Macedonii 1944-2001, Kraków 2014, s. 32.

Suljević K., Nacionalnost Muslimana između teorie i politike, Rijeka 1981.

Talevski J. D., The Borders of the Republic of Macedonia, Bitola 1998.

Prace zbiorowe:

Goranci, muslimani i Turci u Šarplaninskim župama Srbije: Problemi sabašnjih uslova života i opstanaka, M. Bursać (red.) Beograd 2000 (Горанци, муслимани и Туричи у Шарпланинским жупама Србије: Проблеми садашњих услова живота и опстанка, red. М. Бурсаћ, Београд, 2000), http://www.rastko.rs/rastko-gora/zbornici/gora2000/mradovanovic.pdf. 
Vo potraga na nacionalniot identitet (Во потрага на националниот идентитет), Ž. Trpevska (red.), Skopje 2012.

Artykuły:

Antonjeviđ D., Etnički identitet Goranca, (Д. Антонјевиђ, Етнички идентитет Горанияа), https:// www.rastko.rs/rastko-gora/zbornici/gora2000/dantonijevic.pdf

Balcer A., Goranci - społeczność słowiańskich muzutmanów na pograniczu albańsko-macedońskim - w poszukiwaniu tożsamości, [w:] Tożsamość narodowa w społeczeństwie multietnicznym Macedonii, red. M. Kawka, I. Stawowy-Kawka, Kraków 2008.

Cocozzelli F., Ethnic Boundaries and Politics in Kocovo, [w:] Ethnic Minorities and Politics in Post-SocialistSoutheastern Europe, red. S. P. Ramet, M. Valenta, Cambridge 2016.

Gashi S., Goranët dhe 'Boshnjakët'-Nërskamëz tjetër për Kosovën!?, „Revista Sharri”, 2012, http:// pashtriku.beepworld.de/files/Histori/sharri/sharri_11_12_11.pdf, s. 24-29 (dostęp 1.09.2016).

Idrizi S., Sto muhadžirskich godina, Pročitajte višse na:http://www.info-ks.net/bosnjaci/historija/28438/sadik-idrizi-sto-muhadzirskih-godina, (dostęp:10.11.2016).

Matej Q., Polemikë me shkas. Njohja e historisë apo kërkesa politike për. Gorën dhe goranë, Përgjigje artikullit të Nazif Doklit "Gora dhe goranët” Kukës 1991, http://pashtriku.beepworld. de/files/Histori/shpalime/qemal_mataj_goranet.27.06.08.htm

Mindak-Zawadzka J., Gorani - ,,lokal” People?, „Sprawy Narodowościowe”, 2007, z. 31.

Poznańska M. W., Tożsamość jako element kultury pedagogicznej współczesnego wychowawcy, „Edukacja Dorosłych”, 1995 nr 2, s. 64-65.

Stawowy-Kawka I., Granice Albanii - najważniejsze daty, [w:] Tantum Historiae. Ksiega ofiarowana profesorowi Mieczysławowi Tantemu w osiemdziesiąta rocznice urodzin, red. P. Żurek, Bielsko-Biała 2008.

Szewczyk W., Zachowania transgresyjne - próba psychologicznego pomiaru, „Przegląd Psychologiczny", 2010, t. 53, nr 4.

Vidoeski B., Goranskiot govor, Prilozi, Skopje 1986, t. XI, z. 2. (Б. Видоески, Горанскиот говор, „Прилози”, Скопје 1986, t. XI, z. 2).

Prasa:

Napad na radnju Goranca u Beogradu, http://www.naslovi.net/tema/193621.

Irena Stawowy-Kawka

\section{Small Minority Groups in the Balkans and the Problem of Their Self-Identification: Transgression Processes on the Example of the Goranie People}

Summary

The article uses the theory of Józef Kozielecki, which is the subject matter of his reflections in his work: Transgresja i kultura. Transgressive actions are actions of the "outside" - changing the existing status quo. At the same time, in this case transgression is directed "towards people" in order for them to unite (so-called community transgressions). Moving from one group to another and adopting a different model of competence, patterns of cultural behaviour, is characteristic for the Goranie people living on the border of Macedonia, Albania and Kosovo. The Goranie, depending on the political, economic, warfare situation, in order to survive or improve their economic situation, directed their steps towards their Slavic neighbours, identifying with them, adopting their life style, 
official language, some customs. In the first years of the 21 st century, it is becoming more and more typical to build a Goranie ethnic identity and to maintain the "Našinski" language, which is used only at home, as it has not been recognized in any country they live in. Further processes of Goranie transgression, a transition from one group to another, in this case to the Albanian group, and adopting a different model of competence, patterns of cultural behaviour are inevitable in the near future. This is mainly due to the difficult economic conditions of the Goranie and the life of the Albanian enclave.

Keywords: transgression, Gora, Goranie, Kosovo, ethnic identity. 